\title{
GCGR Gene
}

National Cancer Institute

\section{Source}

National Cancer Institute. GCGR Gene. NCI Thesaurus. Code C157478.

This gene is involved in glucose homeostasis. 